\title{
PEMANFAATAN LIMBAH ABU INSENERATOR SEBAGAI BAHAN TAMBAHAN PADA PEMBUATAN GENTENG BETON DALAM KAITANNYA DENGAN KUAT LENTUR GENTENG
}

\author{
Putri Rusmayanti, Gina Bachtiar, Nira Nasution
}

\begin{abstract}
The purpose of this research is to find out the influence of the incenerator ash to the bending strength of the concrete roofing tile with 10\%, 20\%,30\% and $40 \%$. This research was conducted in Industrial Department of DKI Jakarta laboratory and concrete roofing tile is made at PD. Patra. The method of this research is experimental method with four kind of treatments wich is, group A $10 \%$ addition, group B with $20 \%$ addition, group B with $30 \%$ addition and group $D$ with $40 \%$ addition. There are 15 tiles for each treatment; ten concrete roofing tiles for the bending strength experiment and 5 concrete roofing tiles for the water absorption experiment. The data which is taken from the research that A's average bonding strength has $274 \mathrm{~kg} / \mathrm{cm}^{2}$ with $12,53 \%$ water absorption, B's average bonding strength has $256 \mathrm{~kg} / \mathrm{cm}^{2}$ with12,09\% water absorption, C's average bonding strength has $228 \mathrm{~kg} / \mathrm{cm}^{2}$ and D's average bonding strength has $187,6 \mathrm{~kg} / \mathrm{cm}^{2}$ with $11,7 \%$ of water absorption. The result of the research is examined with the Variance Analysis one tail with $\alpha=0,01$ and it is gamed that $F_{\text {hitung }}=99,64$ that mark is higher than $F_{\text {tabel }}=4,38$. So, from this research it can be concluding that the higher addition of incenerator ash to the concrete roofing tile, the higher bonding strength of the concrete roofing tile
\end{abstract}

Keyword : the incenerator ash, bending strength, concrete roofing tile

\section{PENDAHULUAN}

Berbagai macam penutup rumah atau atap yang dikenal sekarang ini dan telah banyak digunakan serta praktis pemasangannya antara lain; asbes, genteng keramik, genteng beton, seng maupun plat beton. Penggunaan genteng beton saat ini relatif lebih banyak digunakan orang, pemilihan genteng beton sebagai penutup atap ini umumnya

\begin{tabular}{|lcr|}
\hline Putri Rusmayawati & Gina Bachtiar, Dra.MT & Nira Nasution, Dra. ST, MPd \\
Alumni Jurusan Teknik Sipil & Staf Pengajar Jurusan Teknik Sipil & Staf Pengajar Jurusan Teknik Sipil \\
Fakultas Teknik & Fakultas Teknik & Fakultas Teknik \\
Universitas Negeri Jakarta, 13220 & Universitas Negeri Jakarta, 13220 & Universitas Negeri Jakarta, 13220 \\
& & \\
& & \\
\hline
\end{tabular}

Jurnal Menara Jurusan Teknik Sipil FT.UNJ

Volume III No.1 - Januari 2008 
didasarkan atas kekuatannya yang relatif lebih baik dan harganya relatif lebih murah.

Pemakaian beton sebagai bahan bangunan mempunyai banyak kelebihan seperti; mudah dibentuk sesuai dengan kebutuhan, perawatan yang murah, dapat memanfaatkan bahan-bahan lokal serta kokoh. Genteng beton merupakan unsur bangunan yang dipergunakan sebagai penutup atap dan dibuat dari bahan campuran beton, dibentuk sedemikian rupa dan berukuran tertentu.

Agar dapat dipergunakan sebagai bahan bangunan atap, genteng harus memenuhi Standar Nasional Indonesia, mengenai ukuran dan bentuk genteng beton serta mutu genteng beton yang meliputi pandangan luar, kekuatan lentur, daya serap air dan ketahanan terhadap rembesan air.

Adanya perkembangan fasilitas kota sebagai tempat pemukiman mengakibatkan peningkatan urbanisasi dan berdampak terhadap kepadatan penduduk perkotaan. Salah satu cara penanganan limbah/sampah perkotaan adalah dengan cara pembakaran dengan tungku (incenerator). Sampah dibakar secara terkendali didalam insenerator dan konstruksi insenerator harus sedemikian rupa sehingga terjadi pembakaran sempurna.

Pembakaran sampah menimbulkan limbah baru yang berupa abu dan hal tersebut dapat menjadi permasalahan karena abu dari sisa pembakaran yang melimpah. Abu insenerator diperoleh dari pembakaran sampah an-organik. Hasil pembakaran sampah dengan insenerator berupa abu sampah ( $23 \%$ dari berat sampah).

Dari uraian di atas penulis tertarik untuk meneliti penggunaan abu insenerator sebagai bahan tambahan pada pembuatan genteng beton. Diharapkan dengan penambahan abu inenerator dapat memberikan peningkatan nilai kuat lentur genteng beton serta sifat-sifat lainnya yang menguntungkan.

Genteng beton adalah unsur bangunan yang dibuat dari campuran bahan-bahan semen portland, agregat halus, air dan pigmen serta bahan tambahan lainnya, yang dibuat sedemikian rupa sehingga dapat digunakan sebagai penutup atap. Genteng yang telah dibuat beraneka macam seperti : genteng beton, genteng keramik, genteng fiber glass, genteng baja dan lain sebagainya.

Syarat-syarat dan mutu genteng beton adalah meliputi : (1) Pandangan luar adalah untuk memperoleh mutu yang baik, permukaan halus, tidak terdapat retak-retak dan bentuknya 
harus seragam, (2) Kuat lentur adalah batas kemampuan yang dimiliki oleh genteng dalam menerima beban maksimum, (3) Daya serap air adalah untuk mengetahui kemampuan genteng beton dalam menyerap air selama 24 jam dan (4) Ketahanan terhadap rembesan air adalah genteng beton harus tahan terhadap rembesan air sehingga tidak terjadi tetesan air dari bawah genteng beton diuji selama 24 jam.

Tujuan dari penelitian ini adalah untuk mengetahui apakah penambahan abu insenerator dengan persentase 10\%, 20\%, 30\% dan 40\% secara signifikan akan berpengaruh terhadap nilai kuat lentur genteng beton.

\section{METODA}

\section{Rancangan Penelitian}

Penelitian ini menggunakan dua kelompok besar benda uji, yaitu kelompok benda uji genteng beton yang diberikan perlakuan dengan variasi penambahan abu insenerator sebagai kelompok uji $\left(E_{1}\right)$ dan kelompok kuat lentur genteng beton tanpa penambahan serat nylon sebagai kelompok pembanding $\left(E_{2}\right)$.

Disain penelitian dapat digambarkan sebagai berikut :

$$
\begin{aligned}
& E_{1} \quad X_{1} \quad-\quad \cdot \quad-\quad-\quad C_{1} \\
& \mathrm{E}_{2} \quad-\quad \mathrm{X}_{2} \quad-\quad-\quad-\quad \mathrm{C}_{2} \\
& \mathrm{E}_{3} \quad-\quad-\mathrm{X}_{3} \quad-\quad \mathrm{C}_{3} \\
& \mathrm{E}_{4} \quad-\quad-\quad-\quad \cdot \quad-\quad \mathrm{X}_{4} \quad \mathrm{C}_{4} \\
& \text { Keterangan: } \quad E_{1,2,3,4}=\text { Kelompok pengerjaan } \\
& X_{1}=\text { Perlakuan yang diberikan penambahan abu insenerator (10\%). } \\
& \mathrm{X}_{2}=\text { Perlakuan yang diberikan penambahan abu insenerator (20\%). } \\
& X_{3}=\text { Perlakuan yang diberikan penambahan abu insenerator } 30 \% \text {. } \\
& X_{4}=\text { Perlakuan yang diberikan penambahan abu insenerator } 40 \% \text {. } \\
& \mathrm{C}_{1,2,3,4}=\text { Hasil penelitan }
\end{aligned}
$$

\section{Prosedur Kerja Laboratorium}

Syarat-syarat dan metode pengujian yang dilakukan di laboratorium berdasarkan 
cara uji kuat lentur genteng beton menurut SNI 03-0096-1999 meliputi persiapan benda uji dan pelaksanaan pengujian.

Untuk prosedur kerja laboratorium dilakukan sebagai berikut :

1. Tahap Pemeriksaan Bahan

Pemeriksaan bahan dilakukan terhadap masing-masing bahan dasar agar diketahui sifat-sifat dari bahan tersebut seperti di bawah ini :

a. Semen

Untuk semen tidak lagi diuji karena sudah memenuhi syarat semen portland. Penelitian ini menggunakan semen type I cap tiga roda.

b. Agregat Halus (pasir)

1. Pemeriksaan zat organik dalam pasir

Tujuannya untuk menentukan adanya kandungan bahan organik dalam pasir, dimana dapat mempengaruhi kualitas genteng beton. Prosedur pengujian ini sesuai dengan SK SNI M-01-1991-03.

2. Pengujian kadar air pasir

Pengujian kadar air pasir sesuai dengan SNI 03-1971-1990.

3. Pengujian kadar lumpur pasir

Pengujian kadar lumpur pasir sesuai dengan SNI 03-1753-1990.

4. Pengujian gradasi pasir

Prosedur penelitian ini sesuai dengan SNI 03-1968-1990.

5. Pengujian specific grafity dan penyerapan air pasir

Prosedur penelitian penyerapan air dengan berat jenis pasir sesuai dengan SNI 03-1970-1990.

6. Pengujian Indeks Kekerasan

Prosedur pengujian untuk pemeriksaan kekerasan sesuai standar industri.

c. Air

Air tidak dilakukan pemeriksaan karena air yang digunakan adalah air PAM yang telah memenuhi standar persyaratan.

Pemanfaatan Limbah Abu Insenerator Sebagai Bahan Tambahan pada Pembuatan Genteng Beton Dalam Kaitannya Dengan Kuat Lentur Genteng Putri Rusmayawati, Gina Bachtiar, Nira Nasution 
2. Tahap Pembuatan Benda Uji

Benda uji dibuat dengan ukuran $42 \mathrm{~cm} \times 34 \mathrm{~cm} \times 1,2 \mathrm{~cm}$ dengan menggunakan mesin pres genteng beton. Pembuatan benda uji genteng beton digunakan perbandingan berat dengan campuran 1 PC : 2 pasir. Sedangkan abu insenerator yang ditambahkan dengan variasi 10\%, 20\%, 30\% dan 40\%. Setelah semua bahan dipersiapkan, maka dilakukan pencampuran dengan molen menjadi adukan yang homogen kemudian dimasukkan kedalam cetakan dan ditekan dengan mesin press.

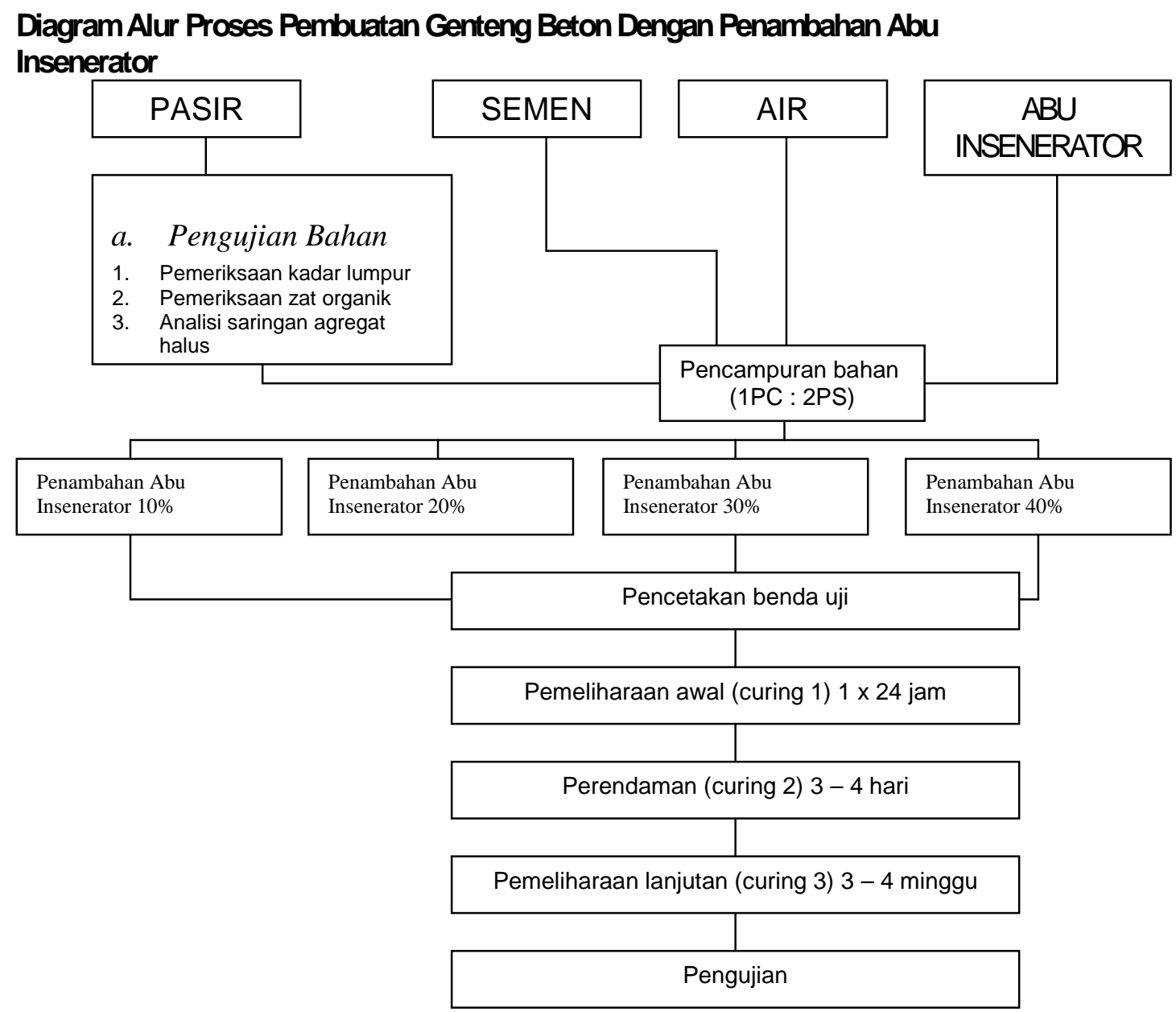

Gambar 1. Diagram Alur Proses Pembuatan Genteng Beton Dengan Penambahan Abu Insenerator 
Sebelum adukan dan masukkan kedalam cetakan terlebih dahulu alat pencetak bagian atas diberi pelumas oli yang telah dipanaskan sebelumnya, kemudian untuk bagian bawah alat pencetak diberi kain penyaring, kain ini dimaksudkan untuk membantu fungsi lubang-lubang yang terdapat pada plat dasar dalam mengurangi jumlah air yang keluar pada saat pengepresan.

Untuk pencetakan genteng ini digunakan cara basah maka pada pengepresan air yang berlebihan dalam adukan akan keluar sehingga genteng yang baru dicetak tersebut memperoleh kekakuan. Setelah itu cetakannya dilepas dengan cara memindahkan pressan genteng diatas tatakan genteng, selanjutnya diletakkan di atas rak-rak penyimpanan.

\section{Tahap Pengujian Benda Uji}

a. Pengujian kuat lentur genteng beton

Pengujian kuat lentur genteng beton sesuai dengan SNI 03-0096-1999. Genteng beton yang telah berumur 28 hari telah siap untuk dilakukan pengujian. Pemeriksaan yang dilakukan sebelum pengujian adalah dengan memeriksa ukuran dan penimbangan berat dari genteng beton tersebut. Hasil pengujian kuat lentur genteng beton sebanyak 60 buah hasilnya berupa nilai kuat lentur rata-rata $\left(\mathrm{kg} / \mathrm{cm}^{2}\right)$.

b. Pengujian daya serap air

Pengujian daya serap air sesuai dengan SNI 03-0096-1999. Daya serap air ratarata dari 10 buah contoh benda uji tidak boleh lebih dari $10 \%$.

c. Pengujian ketahanan terhadap perembesan air (rapat air)

Pengujian ketahanan terhadap perembesan air (rapat air) sesuai dengan SNI 030096-1999. Pengujian ini dilakukan paling sedikit 3 buah contoh uji. Apabila contoh genteng diuji, maka pada setiap genteng tidak boleh terjadi tetesan air dari bagian bawahnya. Apabila genteng menjadi basah tetapi tidak terdapat tetesan air, maka dinyatakan tahan terhadap perembesan air

Pemanfaatan Limbah Abu Insenerator Sebagai Bahan Tambahan pada Pembuatan Genteng Beton Dalam Kaitannya Dengan Kuat Lentur Genteng Putri Rusmayawati, Gina Bachtiar, Nira Nasution 


\section{HASIL DAN PEMBAHASAN}

Percobaan penelitian dilakukan terhadap benda uji, pada pengujian ukuran, daya serap air, kerapatan air dan kuat lentur, secara lengkap hasil penelitian dapat dilihat sebagai berikut Pengujian Ukuran Genteng Beton

Tabel 1. Ukuran Rata-rata Genteng Beton

\begin{tabular}{|c|c|c|c|c|}
\hline \multirow{2}{*}{ Kelompok } & \multicolumn{4}{|c|}{ Ukuran Genteng Beton } \\
\cline { 2 - 5 } & Berat $(\mathrm{kg})$ & Panjang $(\mathrm{mm})$ & Lebar $(\mathrm{mm})$ & Tebal $(\mathrm{mm})$ \\
\hline \hline A (10\%) & 4690 & 418,6 & 330,8 & 14,7 \\
\hline B (20\%) & 4630 & 418,2 & 330,79 & 14,8 \\
\hline C (30\%) & 4600 & 418,3 & 330,75 & 14,7 \\
\hline D (40\%) & 4530 & 419,64 & 330,75 & 14,3 \\
\hline
\end{tabular}

Tabel 2. Ukuran Rata-rata Penampang Tepi

\begin{tabular}{|c|c|c|c|c|}
\hline \multirow{2}{*}{ Kelompok } & \multicolumn{4}{|c|}{ Ukuran Penampang Tepi } \\
\cline { 2 - 5 } & Tebal $(\mathrm{mm})$ & Lebar $(\mathrm{mm})$ & Dalam Alur (mm) & Jumlah Alur \\
\hline $\mathrm{A}(10 \%)$ & 12,60 & 38,18 & 2,52 & 2 \\
\hline $\mathrm{B}(20 \%)$ & 12,85 & 39,60 & 2,82 & 2 \\
\hline $\mathrm{C}(30 \%)$ & 13,35 & 38,64 & 2,57 & 2 \\
\hline $\mathrm{D}(40 \%)$ & 12,95 & 38,43 & 2,41 & 2 \\
\hline
\end{tabular}

Tabel 3. Ukuran Rata-rata Kaitan Tepi

\begin{tabular}{|c|c|c|c|}
\hline \multirow{2}{*}{ Kelompok } & \multicolumn{3}{|c|}{ Kaitan } \\
\cline { 2 - 4 } & Lebar $(\mathrm{mm})$ & Panjang $(\mathrm{mm})$ & Tinggi $(\mathrm{mm})$ \\
\hline A (10\%) & 14,83 & 55,89 & 8,91 \\
\hline B (20\%) & 14,79 & 54,50 & 8,48 \\
\hline C (30\%) & 15,18 & 55,39 & 8,67 \\
\hline D (40\%) & 14,80 & 52,86 & 8,44 \\
\hline
\end{tabular}

Dari tabel di atas dapat dilihat bahwa genteng beton semakin banyak persentase penambahan Abu Insenerator berat genteng beton semakin ringan. 


\section{Hasil Pengujian Kuat Lentur Genteng Beton}

Hasil pengujian rata-rata kuat lentur genteng beton dapat di lihat pada tabel berikut ini.

Tabel 4. Hasil Pengujian Rata-rata Kuat Lentur Genteng Beton

\begin{tabular}{|c|c|}
\hline Kelompok & Nilai Rata-rata Kuat Lentur $(\mathrm{Kg} / \mathrm{cm} 2)$ \\
\hline $\mathrm{A}(10 \%)$ & 274 \\
\hline $\mathrm{B}(20 \%)$ & 256 \\
\hline $\mathrm{C}(30 \%)$ & 228 \\
\hline $\mathrm{D}(40 \%)$ & 187,6 \\
\hline
\end{tabular}

\section{Hasil Daya Serap Air dan Kerapatan Air}

Tabel 5. Hasil Pengujian Rata-rata Daya Serap Air dan Kerapatan Air

\begin{tabular}{|c|c|c|}
\hline Perlakuan & Daya Serap Air (\%) & Kerapatan Air \\
\hline A $(10 \%)$ & 12,53 & Tidak rembes \\
\hline B $(20 \%)$ & 12,09 & Tidak rembes \\
\hline C $(30 \%)$ & 12,81 & Tidak rembes \\
\hline D $(40 \%)$ & 11,7 & Tidak rembes \\
\hline
\end{tabular}

Menurut SNI 03-0096-1999 daya serap air untuk setiap genteng beton tidak lebih dari 10\%. Dari tabel di atas didapat bahwa nilai daya serap air dengan penambahan abu insenerator tidak memenuhi standar karena melebihi 10\% dari yang disyaratkan.

\section{Uji Normalitas}

\section{a. Persentase Penambahan Abu Insenerator 10\%}

Hasil pengujian normalitas dari data nilai kuat lentur genteng beton dengan persentase penambahan abu insenerator $10 \%$ menghasilkan $\mathrm{Lo}=0,1038$, pada taraf signifikan $(\alpha)=0,01$ diperoleh nilai $L=0,2940$, dengan kriteria pengujian apabila $L 0<L$ maka data berdistribusi normal, dengan demikian dapat disimpulkan bahwa populasi kelompok berdistribusi normal.

Pemanfaatan Limbah Abu Insenerator Sebagai Bahan Tambahan pada Pembuatan Genteng Beton Dalam Kaitannya Dengan Kuat Lentur Genteng Putri Rusmayawati, Gina Bachtiar, Nira Nasution 


\section{b. Persentase Penambahan Abu Insenerator $20 \%$}

Hasil pengujian normalitas dari data nilai kuat lentur genteng beton dengan persentase penambahan abu insenerator $20 \%$ menghasilkan $L 0=0,2478$, pada taraf signifikan $(\alpha)=0,01$ diperoleh nilai $L=0,2940$, dengan kriteria pengujian apabila $L 0<L$ maka data berdistribusi normal, dengan demikian dapat disimpulkan bahwa populasi kelompok berdistribusi normal.

\section{c. Persentase Penambahan abu insenerator $30 \%$}

Hasil pengujian normalitas dari data nilai kuat lentur genteng beton dengan persentase penambahan abu insenerator 30\% menghasilkan Lo $=0,1443$, pada taraf signifikan $(\alpha)=0,01$ diperoleh nilai $L=0,2940$, dengan kriteria pengujian apabila $L 0<L$ maka data berdistribusi normal, dengan demikian dapat disimpulkan bahwa populasi kelompok berdistribusi normal.

\section{d. Persentase Penambahan abu insenerator $40 \%$}

Hasil pengujian normalitas dari data nilai kuat lentur genteng beton dengan persentase penambahan abu insenerator $40 \%$ menghasilkan $L 0=0,1420$, pada taraf signifikan $(\alpha)=0,01$ diperoleh nilai $L=0,2940$, dengan kriteria pengujian apabila $L o<L$ maka data berdistribusi normal, dengan demikian dapat disimpulkan bahwa populasi kelompok berdistribusi normal

\section{Uji Homogenitas}

Analisa statistik yang digunakan untuk menguji homogenitas adalah Uji Bartlet. Data yang diuji adalah data kuat lentur dari masing-masing kelompok sampel. Dari perhitungan diperoleh $X^{2}$ hitung $=2,227$, jika taraf nyata $(\alpha)=0,01$ dari daftar ChiKuadrat dengan $\mathrm{dk}=9$ di dapat $\mathrm{X}^{2}{ }_{\text {tabel }}=11,3$ sehingga $\mathrm{X}^{2}{ }_{\text {hitung }}<\mathrm{X}^{2}$ tabel, maka dapat disimpulkan varians dari ketiga kelompok homogen.

\section{Pengujian Hipotesis}

Pengujian kuat lentur genteng beton yang menggunakan abu insenerator dengan persentase $10 \%, 20 \%, 30 \%$ dan $40 \%$, hipotesis nol $\left(\mathrm{H}_{0}\right)$ sebagai berikut : terdapat 
perbedaan yang signifikan dari persentase penambahan abu insenerator terhadap nilai kuat lentur genteng beton.

Untuk mendapatkan hasil pengujian maka data penelitian dianalisa dengan menggunakan uji Analisis Varians (ANAVA) satu arah dengan taraf signifikan $(\alpha)=0,01$, dimana $F_{\text {hitung }}=99,64$ dan $F_{\text {tabel }}=4,38$ jadi $F_{\text {hitung }}>F_{\text {tabel, }}$ maka $H_{0}$ ditolak. Sehingga terbukti ada perbedaan yang signifikan dalam hal ini nilai kuat lentur genteng beton yang menggunakan abu insenerator dengan persentase penambahan 10\%, 20\%,30\% dan 40\%.

\section{PEMBAHASAN}

Dilihat dari hasil penelitian di atas terdapat pengaruh yang signifikan terhadap nilai kuat lentur genteng beton yang menggunakan penamabahan abu insenerator sebagai bahan tambahan 1\%, 20\%, 30\% dan 40\%. Dari hasil penelitian menunjukan semakin bertambahnya persentase abu insenerator, maka makin ringan berat yang dihasilkan serta jumlah genteng yang dihasilkan semakin banyak. Sedangkan penyerapan air yang dihasilkan semakin tinggi. Kuat lentur genteng beton yang menggunakan abu insenerator dengan persentase penambahan 10\% menghasilkan kuat lentur rata-rata $274 \mathrm{~kg} / \mathrm{cm}^{2}$, untuk persentase $20 \%$ menghasilkan kuat lentur rata-rata $256 \mathrm{~kg} / \mathrm{cm}^{2}$, persentase $30 \%$ menghasilkan kuat lentur $228 \mathrm{~kg} / \mathrm{cm}^{2}$ dan dengan penambahan 40\% menghasilkan kuat lentur rata-rata $187,6 \mathrm{~kg} / \mathrm{cm}^{2}$.

Hasil yang diperoleh dari penelitian ini jelas memberikan perbedaan terhadap nilai kuat lentur rata-rata kuat lentur genteng beton yang dihasilkan jika menggunakan abu insenerator sebagai bahan tambahan. Pada penambahan abu insenerator $40 \%$ nilai ratarata kuat lentur yang dihasilkan sebesar $187,6 \mathrm{~kg} / \mathrm{cm}^{2}$ secara signifikan pada $\alpha=0,01$ lebih besar dari nilai kuat lentur genteng beton Standar Nasional Indonesia kelas Mutu I $\left(200 \mathrm{~kg} / \mathrm{cm}^{2}\right)$.

Dengan demikian dengan bertambahnya persentase penambahan abu insenerator pada pembuatan genteng beton, maka kuat lentur rata-rata genteng beton yang dihasilkan semakin rendah.

Pemanfaatan Limbah Abu Insenerator Sebagai Bahan Tambahan pada Pembuatan Genteng Beton Dalam Kaitannya Dengan Kuat Lentur Genteng Putri Rusmayawati, Gina Bachtiar, Nira Nasution 


\section{KESIMPULAN}

Berdasarkan hasil penelitian, maka dapat disimpulkan sebagai berikut:

1. Terdapat perbedaan yang signifikan dalam hal kuat lentur antara genteng beton yang menggunakan abu insenerator sebagai bahan tambahan dengan persentase $10 \%$, $20 \%, 30 \%$, dan $40 \%$ pada pembuatan genteng beton.

2. Nilai kuat lentur genteng beton yang menggunakan abu insenerator $10 \%, 20 \%, 30 \%$ dan $40 \%$ sebagai bahan tambahan lebih tinggi dari kuat lentur minimum yang disyaratkan Standar Nasional Indonesia.

3. Semakin banyak penambahan abu insenerator yang diberikan maka nilai kuat lentur genteng beton semakin kecil.

4. Dengan penambahan abu insenerator $10 \%, 20 \%, 30 \%$, dan $40 \%$ daya serap air yang diperoleh melebihi batas daya serap minimum yang ditentukan yaitu $10 \%$.

\section{DAFTAR PUSTAKA}

Balai Penelitian Bahan, Petunjuk Praktis Proses Pembuatan Genteng Beton, (Jakarta : Departemen Perindustrian, 1996).

Balai Besar Penelitian dan Pengembangan Bahan dan Barang Teknik, Petunjuk Teknis Untuk Pelaksanaan Pengendalian Mutu Genteng Beton, (Bandung : Yayasan LPMB, 1994).

Damanhuri, Erna, Drs. Pengelolaan Limbah Padat. Kantor Menneg. Lingkungan HidupTeknik Lingkungan ITB. Bandung: 1997

Departemen Pekerjaan Umum, Spesifikasi Bahan Bangunan Bagian A (bahan Bangunan Bukan Logam) SK SNI S-04-1989-F, (Bandung : Yayasan LPMB, 1989).

SNI 03-0096-1999, Genteng Beton, (Dewan Standardisasi Nasional, 1999).

Sudjana, Metode Statistika, (Bandung : Tarsito, 1992).

Komarudin, Pembangunan Perkotaan Berwawasan Lingkungan. Jakarta : Dir.Jend. Cipta Karya, Departemen Pekerjaan Umum-BPPT 1999 